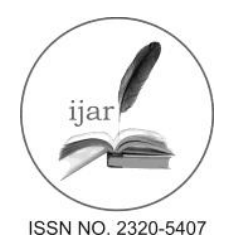

\section{Journal homepage:http://www.journalijar.com Journal DOI:10.21474/IJAR01}

\section{RESEARCH ARTICLE}

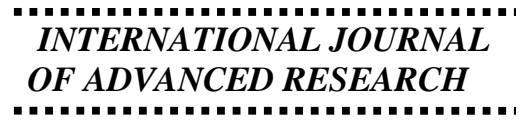

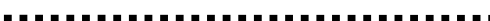

\title{
Synthesis and Characterization of Ternary Copper(II) Complexescontaining L-Valine. Catechol Oxidase and Phenoxazinone Synthase Biomimetic Catalytic Activity.
}

Shaban Y. Shaban, Abd El-Motaleb M. Ramadan, and FawzyaI.El-Shamy. Chemistry Department, Faculty of Science, KafrelsheikhUniversity, Kafrelsheikh Egypt.

\section{Manuscript Info}

Manuscript History:

Received: 19 March 2016

Final Accepted: 29 April 2016

Published Online: May 2016

Key words:

Synthesis, characterization, macrocyclic, copper(II) complexes,

biomimetic, catalytic activity, catechol oxidase, phenoxazinone synthase, Kinetic measurements.

*Corresponding Author

Shaban Y. Shaban.

\begin{abstract}
A new series of ternary copper(II) complexes having molecular formulae $\left[\mathrm{CuLL}^{\prime} \mathrm{X}\right]$ and [CuLL']X has been synthesized. For this ligand system LL', L is the amino acid $\mathrm{L}$-Valine and $\mathrm{L}^{\prime}$ is 2 -aminomethyl pyridine while $\mathrm{X}^{-}$is $\mathrm{Cl}^{-}, \mathrm{Br}^{-}, \mathrm{NO}_{3}{ }^{-}, 1 / 2 \mathrm{SO}_{4}{ }^{2-}$ or $\mathrm{ClO}_{4}{ }^{-}$. The structure characterization of these newly synthesized copper(II) complexes was achieved by various physicochemical techniques, viz. elemental analysis, Thermal analysis (TGA and DTG), magnetic susceptibility measurements, IR, electronic, and EPR spectral studies. The spectral and magnetic measurements in addition to the electrolytic conductance results indicate that complex 2 is five -coordinate square pyramidal while the other complex species are found to have fourcoordinate square-pyramidal geometry. It has been shown that the stereochemistry of complexes is dependent on the type of counter anions incorporated in the complex molecule.

The kinetics and mechanism of substitution by thiourea (TU) were studied in detail as a function of nucleophile concentration in methanol as solvent. The kinetics showed that the substitution reaction of all complexes is a biphasic process. Mimicking copper-oxidase enzymes namely catechol oxidase and phenoxazinone synthase was investigated and the results obtained demonstrated that, the reported copper(II) complexes are suitable as catalysts for the catalytic aerobic oxidation of 3,5-di-tert-butylcatechol(3,5-DTBCH 2$)$ to 3,5-di-tert-butyl-benzoquinone (3,5-DTBQ) (catechol oxidase activity), and $o$-aminophenol (OAPH) to 2-aminophenoxazine-3-one (APX) (phenoxazinone synthase activity) with dioxygen at ambient condition in good yields.
\end{abstract}

Copy Right, IJAR, 2016, All rights reserved.

\section{Introduction:-}

Bioinorganic chemistry has an increase of interest specially in complexes containing N, O-donor ligands as many of these complexes may serve as models for biologically important species having $\mathrm{N}$ and $\mathrm{O}$ as bonding sites [1]. Amino acids and their derivatives, as typical N, O-donor ligands, have been extensively studied. Amino acids containing amine and carboxylic acid groups attached to the first, or alpha, carbon atom have particular importance in biochemistry [2]. Copper $\alpha$ amino acid complexes attract attention of chemists because of its different kind of applications [3]. Copper complexes containing L-valine, one of these $\alpha$ amino acids, has been investigated intensively in the last decade [4]. Copper complexes with 2-aminomethylpyridine (ampy) (known also as picolylamine) are known for their mainly chelating manner of coordination[5].

Catechol oxidase (CO), also known as $o$-diphenoloxidase, is a less well known member of the type-3 copper proteins.Catechol oxidase catalyzes the oxidation of $o$-diphenols (catechols) to the quinones through four-electron reduction of dioxygen to water, [6] whereas Phenoxazinone synthase enzyme catalyzes the overall six-electron oxidative coupling of 2-aminophenol to form 2-aminophenoxazinone.[7] 
In a quest of mimicking catechol oxidase and phenoxazinonesynthese enzymes, a new ternary copper(II) complexes with mixed ligands of an ONNN-donors derived from L-valine and 2-aminomethylpyridine have been synthesized and characterized. Further, the ligand substitution properties of the complexes as well as the catechol oxidase and phenoxazinone syntheses activity are reported and correlated with the structure

\section{Experimental:- \\ Materials:-}

All chemicals used were of analytical grade. 2-aminomethyl pyridine, L-Valine and copper(II) salts were purchased from Aldrich..

\section{Synthesis of copper(II) complexes 1-5:-}

To the mixture of L-Valine ( $2 \mathrm{mmol})$ and $\mathrm{NaOH}(2 \mathrm{mmol})$ in water, an ethanolic solution of ( $2 \mathrm{mmol})$ copper(II) salt $\left\{\mathrm{CuX}_{2} ; \mathrm{X}^{-}=\mathrm{Cl}^{-}, \mathrm{Br}^{-}, \mathrm{NO}_{3}^{-}, 1 / 2 \mathrm{SO}_{4}{ }^{2-}\right.$ or $\left.\mathrm{ClO}_{4}{ }^{-}\right\}$, was added with stirring. Several minutes later, ethanolic solution (5 $\mathrm{mL}$ ) of 2-aminomethyl pyridine $(2 \mathrm{mmol})$ was added and then the solution was stirred for about one $\mathrm{h}$ at room temperature. The resulting solution was left to evaporate at room temperature where a large amount of colored precipitate was produced, which was filtered and washed with ethanol, ether and finally dried in vacuum desiccator over $\mathrm{CaO}$.

\section{Instrumentation and Measurements:-}

IR spectra were recorded using $\mathrm{KBr}$ disks in the 4000-200 $\mathrm{cm}^{-1}$ range on a Unicam SP200 spectrophotometer. The electronic absorption spectra were obtained in DMF solution with a Shimadzu UV-240 spectrophotometer. Magnetic moments were measured by Gouy's method at room temperature. ESR measurements of the polycrystalline samples at room temperature were made on a Varian E9 X-band spectrometer using a quartz Dewar vessel. All spectra were calibrated with DPPH $(\mathrm{g}=2.0027)$. The specific conductance of the complexes was measured using freshly prepared $10^{-3} \mathrm{M}$ solutions in electrochemically pure DMF at room temperature, using an YSI Model 32 conductance meter. The thermogravimetric measurements were performed using a Shimadzu TG 50-Thermogravimetric analyzer in the $25-1000{ }^{\circ} \mathrm{C}$ range and under an $\mathrm{N}_{2}$ atmosphere. Elemental analyses $(\mathrm{C}, \mathrm{H}$, and $\mathrm{N}$ ) were carried out at the Micro analytical Unit of Cairo University.Kinetic investigations of the substitution by thiourea were performed on KinetAsyst SF-61DX2stopped-flow instrument (also thermostated at $23.0 \pm 0.1{ }^{\circ} \mathrm{C}$ ) with an optical pathlength of 1 $\mathrm{cm}$ at $300 \mathrm{~nm}$. The ligand substitution reactions were studied under pseudo-first-order conditions by using at least a ten-fold excess of thiourea. All listed rate constants represent an average value of at least three kinetic runs under each experimental condition.

\section{Oxidase biomimetic catalytic activity:-}

A mixture of $1.0 \mathrm{ml}$ of studied substrate 3,5-di-tert-butylcatehol (3,5-DTBCH$)$ or $o$-aminophenol (OAPH) solution $(30 \mathrm{mM})$ in methanol and $1.0 \mathrm{ml}$ of copper complex solution $(\sim 3 \mathrm{mM})$ in methanol was placed in a $1 \mathrm{~cm}$ path length optical cell containing $1.0 \mathrm{ml}$ of methanol in a spectrophotometer. The final concentration of reaction mixture is catechol or $o$-aminophenol $(10 \mathrm{mM})$ and complex $(1 \mathrm{mM})$. The formation of 3,5-di-tert-butyl-quinone (3,5-DTBQ) was followed by observing the increase of characteristic quinone absorption band at $400 \mathrm{~nm}$ and for 2 -amino-3Hphenoxazine-3-one (APX) at $433 \mathrm{~nm}$.

\section{Results and discussion:-}

A new series of ternary copper(II) complexes $\left(\mathrm{CuLL}^{\prime} \mathrm{X}\right)$ were prepared in the molar ratio $1: 1: 1$ from the amino acid, L-Valineas L, the bidentate nitrogen bases in the function of $\mathrm{L}^{\prime} 2$-aminomethyl and copper(II) ion with the various counter anions, $\mathrm{X}^{-}$, where $\mathrm{X}^{-}$isCl ${ }^{-}, \mathrm{Br}^{-}, \mathrm{NO}_{3}^{-}, 1 / 2 \mathrm{SO}_{4}{ }^{2-}$ or $\mathrm{ClO}_{4}^{-}$. This ligand system (LL') in $1: 1$ stoichiometry is a mono anionic tetradentate chelating mixed ligand providing the coordination chromophore $\mathrm{N}_{3} \mathrm{O}$ (Scheme 1). L-Valine behaves as mono basic bidentate so the resulting copper(II) complexes have one positive charge balanced by the counter anion. Molecular formulae of the reported chelates were principally identified based on elemental analysis data and the molar conductance behavior of these chelates in methanol solution. The analytical data, listed in Table 1, are in close agreement with the calculated values for the molecular formulae assigned to these ternary copper(II) complexes. On contrary the fully structural characterization was achieved based on the employed spectral investigations, magnetic and electrochemical measurements. The nature of water content in the hydrated complexes was inferred from the thermal analysis (TGA and DTG) results. 


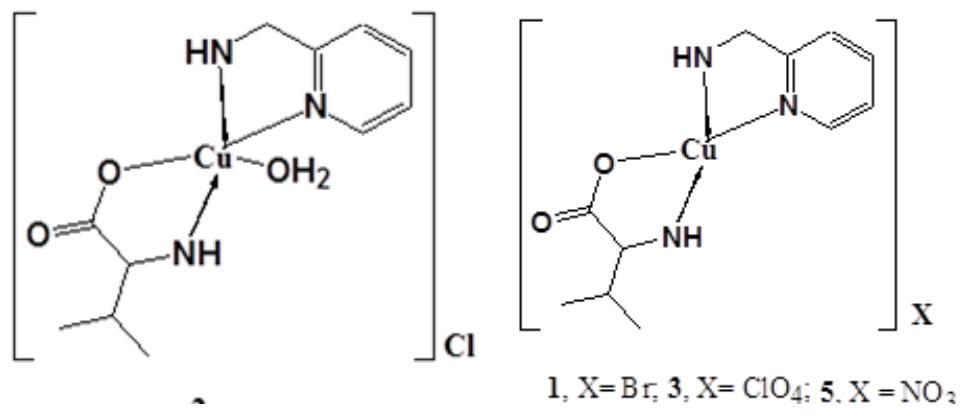

Scheme 1; Schematic representation of the prepared copper complexes 1-3 and $\mathbf{5}$.

These newly synthesized copper(II) complexes are non-hygroscopic in nature and stable as solids or in solution under the atmospheric conditions. They are colored microcrystalline solids and their color being various shades of blue and violet (Table 1). They are insoluble in common organic solvents viz. ethanol, chloroform, benzene, cyclohexane, acetone, diethyl ether, etc., but are freely soluble in water, MeOH, DMF and DMSO. The complexes are cationic with one of the metal charge entirely neutralized by the singly deprotonated carboxylate group of this mixed ligand system. In spite of all the effort, none of these copper(II) complexes could be crystallized for their single crystal X-ray diffraction studies.

The electrolytic conductivity measurements for $c a 10^{-3} \mathrm{molL}^{-1}$ of the monomeric complex species containing the counter anions chloride, bromide, perchlorateand nitrate in methanol solution at room temperature show molar conductance values $\left(84.55-105.00 \Omega^{-1} \mathrm{~mol}^{-1} \mathrm{~cm}^{2}\right)$ indicate that they are 1:1 electrolytes [8]. This finding suggests the nonparticipation of these associated counter anions in the coordination chromophores and consequently these counter anions are not bound directly to the copper(II) center of these ternary copper(II) chelates. Also the observed low electrical conductance values (Table 2) for the sulfato complexes in the methanolic solution indicatetheir nonelectrolytic nature and suggests the participation of sulfato group in the coordination sphere as a bridge in a dimeric structure (Scheme 1). This conclusion is further supported by the spectral results, e. g. IR and ESR and also confirmed from the magnetic moment measurements.

\section{Thermal analysis:-}

Thermal decomposition (TGA and DTG) :-

Thermal decomposition studies on the present synthesized copper(II) complexes 1, 2, $\mathbf{4}$ and $\mathbf{5}$ have been carried out so as to corroborate the information obtained from their molar conductance and spectral studies about the statues of water molecules present in these complexes, as well as to know their general decomposition patterns. The thermogravimetric analysis was carried out in $\mathrm{N}_{2}$ atmosphere from the ambient temperature up to $800{ }^{\circ} \mathrm{C}$. The calculated weight losses percentage were estimated based on the TG data and agree quit well with the suggested molecular formulae of the investigated complexes. A representative thermogram of these hydrated complexes is given in Figure 1.

The decomposition stages, temperature ranges, maximum decomposition peak DTG $_{\max }$, percentage mass losses of the decomposition reactions together with their theoretical percentage mass losses and the assignments of decomposition moieties are given in Table 2 which revealed the following findings:

The hydrated complexes 1, 2, 4 and 5 exhibit similar thermal degradation behaviors as inferred from their TGA thermograms. Their thermal decomposition occurs in successive stages within the temperature range $60-800{ }^{\circ} \mathrm{C}$. The first stage shows the dehydration process which starts at $50{ }^{\circ} \mathrm{C}$ and comes end at $145^{\circ} \mathrm{C}$ with the maximum decomposition peaks DTG $\mathrm{max}_{\max }$ at, 50,140 and $120^{\circ} \mathrm{C}$ for complexes 1, 2, 4 and $\mathbf{5}$ respectively. The percentage of weight loss is corresponding to the volatilization of the lattice water content with a mass loss of $(2.35-4.76)$ in an agreement with the theoretical values of $(2.55-4.79)$. The activation energy value of this thermal dehydration step is $2.22-8.85 \mathrm{~kJ} \mathrm{~mol}^{-1}$ (Table 3). This ease of desolvation suggests the weak interaction of water; i. e. water plays little or no role in the lattice forces and occupies crystal voids. 
For complexes 1, 4 and $\mathbf{5}$ the formed anhydrous intermediates were further thermally decomposed within the second thermal pyrolysis stage. The second thermal degradation at the temperature range $160-250{ }^{\circ} \mathrm{C}$ ascribed to the elimination ofthe non-coordinated electrolytic counter anions in addition to a partial decomposition of the organic ligand system with a mass loss of $(28.2-65.62 .00 \%)$ in accordance with calculated values of $(22.28-65.63 \%)$.

The third thermal degradation of complexes $\mathbf{1}, \mathbf{4}$ and $\mathbf{5}$ at the temperature range $220-650{ }^{\circ} \mathrm{C}$ with the maximum decomposition peaks $\mathrm{DTG}_{\max }$ extending from 260 to $590{ }^{\circ} \mathrm{C}$ (Table 2) attributed to the elimination of the remaining organic moiety with a mass loss values of $(8.81-47.98 \%)$ in an almost agreement with the calculated values of $(8.73-47.41 \%)$. This significant mass loss leaved behind copper(II) oxide $(\mathrm{CuO})$ as the final product of the thermal pyrolysis of the investigated complex molecules. The total loss of weight agrees well with the corresponding calculated data (Table 2).

Concerning complex 2 the second thermal degradation stage at the temperature range $80-160{ }^{\circ} \mathrm{C}$ with the maximum decomposition peaks $\mathrm{DTG}_{\max }$ at $120{ }^{\circ} \mathrm{C}$ ascribed to volatilization of the coordinated water molecule. The detected mass loss of $4.66 \%$ is in an almost agreement with the calculated value of $4.79 \%$. The third thermal degradation stage at the temperature range $160-220{ }^{\circ} \mathrm{C}$ with the maximum decomposition peaks $\mathrm{DTG}_{\max }$ at $200{ }^{\circ} \mathrm{C}$ ascribed to the elimination of the non-coordinated chloride ion in addition to a partial decomposition of the organic moiety with a mass loss of $30.45 \%$ in an almost agreement with the calculated value of $30.32 \%$. The fourth final pyrolysis step within the temperature range $220-360{ }^{\circ} \mathrm{C}$ with the maximum decomposition peak $\mathrm{DTG}_{\max }$ at $350{ }^{\circ} \mathrm{C}$ attributed to the loss of the rest of the organic ligand system in the complex molecule in successive unresolved steps with an observed mass loss value of $38.54 \%$ in an agreements with the calculated value of $38.76 \%$ giving rise to the final residual $\mathrm{CuO}$.

For all complexes, the metal content, determined from the oxide residue, was found to be satisfactory agreement with values calculated on the basis of the suggested composition formulae based on the elemental analysis data.

\section{Thermal Kinetic Studies:-}

All the well characterized decomposition stages of the synthesized copper(II) complexes 1, 2, 4 and 5 were selected for the study of the kinetics of decomposition. The thermodynamic parameters of the decomposition processes namely, activation energy $\left(E_{\mathrm{a}}^{\#}\right)$, enthalpy $\left(\Delta H^{\#}\right)$, entropy $\left(\Delta S^{\#}\right)$, and Gibbs free energy change $\left(\Delta G^{\#}\right)$ were evaluated graphically by employing the Coats-Redfern equation [9]. The values of various kinetic parameters calculated are given in (Table 3). The activation energies $\left(E_{a}\right)$ in the different stages of thermal decomposition of the investigated complexes are in the range of $6.98-15.21 \mathrm{k} \mathrm{J} \mathrm{mol}^{-1}$. The corresponding values of the pre-exponential factor $(A)$ of the different thermal degradation stagesare in the range of $1.197-9.86 \mathrm{~s}^{-1}$. The respective values of the entropy of activation $(\Delta S)$ are in the range of -0.8356 to $-0.856 \mathrm{~J} \mathrm{~mol}^{-1}$. Neither the values of $A$ nor the values of $\Delta S$ show a definite trend along the series, but the energy of activation for the second-stage decomposition is almost higher than that of the first stage. As well as the activation energy of the second-stage decomposition is almost lower than that of the third final stage.

For all complexes, in most thermal degradation steps the values of $\Delta G$ increase for the subsequently decomposition stages due to increasing the values of $\mathrm{T} \Delta \mathrm{S}$ from one step to another which override the value of $\Delta \mathrm{H}$. This increase reflects that the rate of the subsequent removal of the coordinated anions and the organic ligand portion will be lower than that of the precedent ligand. This may be ascribed to the structural rigidity of the remaining complex after the explosion of the lattice or surface water molecule and one of the coordinated bromide anion as compared with precedent complex, which require more energy for its rearrangement before undergoing any compositional change. The positive values of $\Delta H$ (Table 3) means that the thermal decomposition processes are endothermic. The negative value of $\Delta S$ observedof all complexes, (Table 3) indicates that the activated complexes have more ordered structure than the reactants.

Thus, on the basis of above discussion which is based upon elemental analysis, molar conductance, magnetic susceptibility, IR, electronic, EPR spectral studies and thermal analysis (TGA \& DTG); the suggested structures of the reported copper(II) $\mathbf{1}-\mathbf{5}$ complexes are given in Scheme 1.

\section{IR Spectra and the Mode of bonding:-}

The results of the IR measurements were tabulated in Table 4, where the band assignments of the guide bands (those affected by coordination) have been given. The IR spectra of the free components of the in suit synthesized 
copper(II) complexes were compared to get information about the coordination behavior of this ligand system with copper(II) ion. The group of bands appearing at $3224-3367 \mathrm{~cm}^{-1}$ can be attributed to the stretching vibrations of the coordinated amino group $\left(\mathrm{NH}_{2}\right)$. The bands around 1586 and $1440 \mathrm{~cm}^{-1}$ are ascribed to the antisymmetric $\left\{v_{\text {asym }}\left(\mathrm{COO}^{-}\right)\right\}$and symmetric stretching vibrations of $\left\{\mathrm{v}_{\text {sym }}\left(\mathrm{COO}^{-}\right)\right\}$of the carboxylate group of the free L-Valine. These bands were appeared in the complexes at $1577-1598$ and $1443-1459 \mathrm{~cm}^{-1}$, indicating the involvement of the carboxylic group in complex formation [10]. The value of $\Delta v\left(\mathrm{~cm}^{-1}\right)$; where $\Delta v=v_{\text {asym }}\left(\mathrm{COO}^{-}\right)-v_{\text {sym }}\left(\mathrm{COO}^{-}\right)=124$ $155 \mathrm{~cm}^{-1}$ is consistent with monodentate coordination of the carboxylate group [11]. Thus, the monovalent anion of $\mathrm{L}-$ Valine is coordinated to the metal ion as a $\mathrm{N}$, O-bidentate ligand, in agreement with the previously reported analogous copper(II) complexes [12]. The band at $1510-1519 \mathrm{~cm}^{-1}$ is most likely assigned to the stretching vibration of the $\mathrm{C}=\mathrm{N}$ group of the pyridine moiety of the co-ligand 2-amino methyl pyridine and confirms its coordination to the metal ion [13]; alternatively, this band could be ascribed to the deformation mode $\mathrm{NH}$ of the N$\mathrm{H}$ group belonging to the amino acid moiety [14]. However, coordination of the pyridine nitrogen to copper(II) ion is inferred from the observation that, the $v(\mathrm{C}=\mathrm{N})_{\mathrm{py}}$ stretching mode band of the 2-amino methyl pyridine ligand in the spectra of the copper(II) complexes is recorded around $1500 \mathrm{~cm}^{-1}$ and this band is at approximately $10-19 \mathrm{~cm}^{-1}$ higher wave numbers than in the free 2-amino methyl pyridine ligand, as a result of the coordination of copper(II) to pyridine nitrogen. The bonding of the pyridine nitrogen atom is also supported by the presence of medium bands at $655-693 \mathrm{~cm}^{-1}$ attributable to the ring breathing frequency and the low energy pyridine ring vibrations, respectively [15]. Furthermore, the formation of complexes was also deduced by the presence of new medium intensity bands around $502-547$ and $410-445 \mathrm{~cm}^{-1}$ corresponding to $\mathrm{Cu}-\mathrm{N}$ and $\mathrm{Cu}-\mathrm{O}$, respectively.

The absorptions due to the lattice water molecules are evidenced in the spectra of hydrated complexes, occurring as a broad absorption at about $3400 \mathrm{~cm}^{-1}$ (Table 4) attributable to the $\mathrm{OH}$ vibration of water molecules in the complexes. The assignment of the absorption at $\approx 3400 \mathrm{~cm}^{-1}$ is supported by the presence of a shoulder to the band at $\approx 1630 \mathrm{~cm}^{-1}$ which is the absorption from a $v(\mathrm{OH})$ bending mode of lattice water.

\section{Electronic absorption spectra:-}

The distinguishing electronic spectral absorption bands of the investigated copper(II) complexes were recorded in solution and the results obtained are listed in Table 5. As shown in Table 5, the electronic absorption spectral data for the four-coordinated complex species $\mathbf{1}, \mathbf{3}, \mathbf{4}$ and $\mathbf{5}$ are all similar and exhibit three weak peaks appearing in the low energy visible region Table 5 . These detected peaks unambiguously be assigned to the three spin allowed transitions: ${ }^{2} B_{1 \mathrm{~g}} \rightarrow{ }^{2} B_{2 \mathrm{~g}},{ }^{2} B_{1 \mathrm{~g}} \rightarrow{ }^{2} A_{1 \mathrm{~g}}$ and ${ }^{2} B_{1 \mathrm{~g}} \rightarrow{ }^{2} E_{\mathrm{g}}$, respectively [16]. These spectral features support to the squareplanar geometry around copper(II) center [17].

Concerning the five coordinate copper(II) complex 2, its electronic absorption spectrum exhibits three weak peaks appearing in the low energy visible region may be attributed to the $d$-d transitions of the copper(II) ion in the squarepyramidal environment $\left(C_{4 \mathrm{v}}\right)$ [18]. In the square - pyramidal copper(II) complexes the plausible d-orbital energy level scheme (idealized symmetry group $C_{4 v}$ ), is $\mathrm{dx}^{2}-\mathrm{y}^{2}>\mathrm{dz}^{2}>\mathrm{d}_{\mathrm{xy}}>\mathrm{d}_{\mathrm{xz}}, \mathrm{d}_{\mathrm{yz}}$. Accordingly, for the present five coordinated copper(II) complexes, the higher energy band of the d-d transitions can be assigned tod ${ }_{x z}, d_{y z} \rightarrow d x^{2}-y^{2}$, $d_{x y} \rightarrow d x^{2}-y^{2}$ and the lower energy band to $\mathrm{dz}^{2} \rightarrow \mathrm{dx}^{2}-\mathrm{y}^{2}$. These spectral parameters are in consistence with the other monomeric copper(II) complexes in the five-coordinate square-pyramidal stereochemistry [19]. This finding is further confirmed from the results of the ESR spectra.

\section{EPR spectra and magnetic moment measurements:-}

The effective magnetic moments (BM) of the investigated copper(II) complexes were measured at room temperature and the results obtained are recorded in Table 6 which demonstrate that the present copper(II) complexes are magnetically dilute. The observed magnetic moments fall in the range $1.94-2.15 \mathrm{BM}$ (Table 6) and indicate the monomeric nature of the complexes. These values are close to the spin only $(S=1 / 2)$ behavior of 1.73 B.M. for $\mathrm{d}^{9}$ configuration and reflects the absence of any metal-metal interaction with the neighboring molecules. This finding is further confirmed from the clear resolution of the ESR spectra. The reported magnetic moment values correspond to one unpaired electron indicating the complexes may be considered as tetragonal geometry.

The X-band ESR spectra of the polycrystalline samples of the reported copper(II) complexes $\mathbf{1}-\mathbf{5}$ were recorded at frequency $9.1 \mathrm{GHz}$ under the magnetic field strength $3100 \mathrm{G}$ scan rate 1000 recorded at room temperature and the results obtained are listed in Table 6. 
For the present four coordinated complexes 1, 3,5 and the other five coordinated complex 2, their EPR spectra show parameters which are characteristic of the axial symmetry with elongation of axial bonds and the orbital $d x^{2}-y^{2}$ is the ground state. Concerning the five coordinated complex 2, elongated square planar or distorted square-pyramidal stereochemistry would be consistent with its ESR data, but trigonal-pyramidal involving compression of the axial bonds should be excluded [20]. The spectra of all complexes show one signal and the absence of the hyperfine splitting may be attribute to a strong dipolar interaction between the copper(II) ions in the unit cell. The trend $\mathrm{g}_{\|}$ $(2.233-2.268)>\mathrm{g}_{\perp}(2.035-2.053)$ observed for these complexes was found to be in accordance with the criterion of Kivelson and Neiman implying the presence of the unpaired electron is localized in $\mathrm{dx}^{2}-\mathrm{y}^{2}$ orbital for copper(II) ion characteristic of the axial symmetry [21]. The ESR data obtained for these four and five-coordinate complexes, together with the position of the $\mathrm{d}-\mathrm{d}$ absorption bands point out to a square planar and square-pyramidal structures [22] where the equatorial plan is determined by the three nitrogen atoms in addition to one counter anion for the square planar structure and two counter anions for the five coordinate square-pyramidal geometry. These ESR parameters and the electronic transitions energies is comparable with that reported for analogous copper(II) complexes containing four-coordinate copper(II) centers in a square-planar stereochemistry [22].

The $g_{\mathrm{av}}$ values were calculated using the relation; $g_{\mathrm{av}}=1 / 3\left(\mathrm{~g}_{\|}+2 \mathrm{~g}_{\perp}\right)$. The average $g$ values (Table 6) are found to be in the range $2.101-2.124$ i. e. above the free ion value (2.0023) which indicates strong covalency in bonding between the copper(II) ion and the ligand molecule [23]. The EPR parameter $\mathrm{G}$ has been calculated by using the expression[24]: $G=\left(g_{\|}-2\right) /\left(g_{\perp}-2\right)$. The value of $G$ reflects the exchange interaction between copper centers in the polycrystalline solid complexes. According to Hathaway et al.[25] values of $G$ less than 4 indicate considerable exchange interaction in the solid complexes while values of $\mathrm{G}$ larger than 4 are typical of negligible exchange interactions, which is the case in the copper(II) complexes under investigation.

Table 1. Molecular formulae, physical prosperities and elemental analytical of copper(II) complexes

\begin{tabular}{|c|c|c|c|c|c|c|}
\hline Complex & Color & $\begin{array}{c}\Lambda_{\mathrm{M}} \\
\left(\Omega^{-1} \mathrm{~cm}^{2} \mathrm{~mol}^{-1}\right) \\
\end{array}$ & $\mathrm{C}$ & \multicolumn{2}{|c|}{$\begin{array}{c}\text { Found (calcd.) } \% \\
\mathrm{H} \quad \mathrm{N} \\
\end{array}$} & $\mathrm{M}$ \\
\hline 1.[ $\left.\mathrm{CuLL}^{\prime}\right] \mathrm{Br} . \mathrm{H}_{2} \mathrm{O}$ & Blue & 84 & $\begin{array}{c}34.16 \\
(34.23)\end{array}$ & $\begin{array}{c}4.63 \\
(5.18) \\
\end{array}$ & $\begin{array}{c}10.55 \\
(10.90)\end{array}$ & $\begin{array}{c}16.57 \\
(16.47) \\
\end{array}$ \\
\hline 2. $\left[\mathrm{CuLL}^{\prime} \mathrm{H}_{2} \mathrm{O}\right] \mathrm{Cl}_{2} \mathrm{H}_{2} \mathrm{O}$ & Blue & 92 & $\begin{array}{c}37.16 \\
(36.76) \\
\end{array}$ & $\begin{array}{r}5.63 \\
(6.12) \\
\end{array}$ & $\begin{array}{c}11.15 \\
(11.70) \\
\end{array}$ & $\begin{array}{r}17.57 \\
(17.69) \\
\end{array}$ \\
\hline 3. $\left[\mathrm{CuLL}^{\prime}\right] \mathrm{ClO}_{4} \cdot \mathrm{H}_{2} \mathrm{O}$ & Violet & 105 & $\begin{array}{c}33.10 \\
(32.58)\end{array}$ & $\begin{array}{c}4.77 \\
(4.93)\end{array}$ & $\begin{array}{c}10.40 \\
(10.37)\end{array}$ & $\begin{array}{c}15.94 \\
(15.67)\end{array}$ \\
\hline 4. $\left[\left(\mathrm{CuLL}^{\prime}\right)_{2} \mathrm{SO}_{4}\right] \mathrm{H}_{2} \mathrm{O}$ & Pale violet & 11 & $\begin{array}{c}38.50 \\
(38.30) \\
\end{array}$ & $\begin{array}{c}3.15 \\
(2.90) \\
\end{array}$ & $\begin{array}{c}12.21 \\
(12.19) \\
\end{array}$ & $\begin{array}{l}18.015 \\
(18.44) \\
\end{array}$ \\
\hline 5. $\left[\mathrm{CuLL}^{\prime}\right] \mathrm{NO}_{3} \cdot \mathrm{H}_{2} \mathrm{O}$ & Violet & 100 & $\begin{array}{c}35.62 \\
(35.91)\end{array}$ & $\begin{array}{c}5.79 \\
(5.44)\end{array}$ & $\begin{array}{c}15.31 \\
(15.24)\end{array}$ & $\begin{array}{c}17.19 \\
(17.28)\end{array}$ \\
\hline
\end{tabular}


Table 2.Thermogravimetric analysis degradation of copper(II) complexes $\mathbf{1 , 2}, \mathbf{4}$ and $\mathbf{5}$

\begin{tabular}{|c|c|c|c|c|}
\hline Complex & $\begin{array}{c}\text { Temperature } \\
{ }^{\circ} \mathrm{C}\end{array}$ & DTG $_{\max }$ & $\begin{array}{l}\% \text { Mass loss } \\
\text { Found (calcd.) }\end{array}$ & Species formed \\
\hline 1 & $\begin{array}{c}50-80 \\
160-220 \\
220-650\end{array}$ & $\begin{array}{c}55 \\
150,210 \\
590\end{array}$ & $\begin{array}{c}3.80(4.48) \\
28.20(28.28) \\
47.98(47.41)\end{array}$ & $\begin{array}{l}{\left[\mathrm{CuLL}{ }^{\prime}\right] \mathrm{Br}} \\
{\left[\mathrm{Cu}\left(\mathrm{LL}^{\prime}\right)_{0.85}\right]} \\
\mathrm{CuO}\end{array}$ \\
\hline 2 & $\begin{array}{c}50-80 \\
80-160 \\
160-220 \\
220-360\end{array}$ & $\begin{array}{c}50 \\
120 \\
200 \\
350\end{array}$ & $\begin{array}{c}4.76(4.79) \\
4.66(4.79) \\
30.45(30.32) \\
38.54(38.76)\end{array}$ & $\begin{array}{l}{\left[\mathrm{CuLL}^{\prime} \mathrm{H}_{2} \mathrm{O}\right] \mathrm{Cl}} \\
{[\mathrm{CuLL}] \mathrm{Cl}} \\
{\left[\mathrm{Cu}\left(\mathrm{LL}^{\prime}\right)_{0.65}\right]} \\
\mathrm{CuO}\end{array}$ \\
\hline 3 & $\begin{array}{l}130-145 \\
220-250 \\
250-550\end{array}$ & $\begin{array}{c}140 \\
240 \\
260,320,480\end{array}$ & $\begin{array}{c}2.35(2.55) \\
32.09(32.67) \\
45.17(44.47)\end{array}$ & $\begin{array}{l}{\left[\left(\mathrm{CuLL}^{\prime}\right)_{2} \mathrm{SO}_{4}\right]} \\
{\left[\mathrm{Cu}\left(\mathrm{LL}^{\prime}\right)_{2 \times 0.7}\right]} \\
\mathrm{CuO}\end{array}$ \\
\hline 4 & $\begin{array}{l}100-140 \\
200-245 \\
245-550\end{array}$ & $\begin{array}{c}120 \\
240 \\
285,440\end{array}$ & $\begin{array}{c}4.54(4.68) \\
65.62(65.63) \\
8.81(8.73)\end{array}$ & $\begin{array}{l}{\left[\mathrm{CuLL}{ }^{\prime}\right] \mathrm{NO}_{3}} \\
{\left[\mathrm{Cu}\left(\mathrm{LL}^{\prime}\right)_{0.15}\right]} \\
\mathrm{CuO}\end{array}$ \\
\hline
\end{tabular}

Table 3. Kinetic and thermodynamic parameters of copper(II) complexes

\begin{tabular}{|l|l|l|l|l|l|l|}
\hline *Comp & $\mathrm{T}^{\circ}(\mathrm{K})$ & $A$ & $E_{a}$ & $\Delta H$ & $\Delta S$ & $\Delta G$ \\
\hline $\mathbf{1}$ & 413 & 2.428 & 6.98068 & 3.5470 & -0.8452 & 352.0 \\
& 493 & 9.263 & 11.49450 & 7.3942 & -0.8356 & 419.0 \\
& 973 & 9.626 & 16.62462 & 8.5346 & -0.8401 & 825.0 \\
\hline $\mathbf{2}$ & 293 & 1.197 & 8.85680 & 6.4256 & -0.8480 & 254.8 \\
& 393 & 8.817 & 5.73452 & 2.46340 & -0.8345 & 330.2 \\
& 493 & 9.865 & 13.01540 & 8.91451 & -0.8343 & 420.0 \\
& 763 & 9.445 & 14.4975 & 8.15540 & -0.8385 & 647.5 \\
\hline $\mathbf{3}$ & 423 & 4.6543 & 5.22601 & 1.70730 & -0.839 & 356.6 \\
& 553 & 8.9074 & 11.3345 & 6.74531 & -0.836 & 469.0 \\
& 843 & 9.4876 & 15.2130 & 8.21874 & -0.839 & 715.0 \\
\hline
\end{tabular}

"Complex details are as listed in Table 1. $E_{\mathrm{a}}, \Delta \mathrm{H}$ and $\Delta \mathrm{G}$ are in $\mathrm{kJ} \mathrm{mol}^{-1}, \Delta \mathrm{S}$ in J mol${ }^{-1}$.

Table 4: IR spectra $\left(\mathrm{cm}^{-1}\right)$ of copper(II) complexes 1- 5

\begin{tabular}{|c|c|c|c|c|c|c|c|c|}
\hline Comp & $v\left(\mathrm{NH}_{2}\right)$ & $v_{\mathrm{as}}(\mathrm{COO})$ & $v_{\mathrm{s}}(\mathrm{COO})$ & $\Delta v$ & $v(\mathrm{C}=\mathrm{N})_{\mathrm{py}}$ & $\delta(\mathrm{C}=\mathrm{N})_{\mathrm{py}}$ & $v(\mathrm{Cu}-\mathrm{N})$ & $v(\mathrm{Cu}-\mathrm{O})$ \\
\hline $\mathbf{1}$ & 3322 & 1596 & 1459 & 137 & 1519 & 693 & 505 & 445 \\
\hline $\mathbf{2}$ & 3268 & 1585 & 1447 & 138 & 1519 & 677 & 506 & 415 \\
\hline $\mathbf{3}$ & 3245 & 1577 & 1453 & 124 & 1512 & 685 & 515 & 420 \\
\hline $\mathbf{4}$ & 3224 & 1597 & 1443 & 154 & 1513 & 684 & 547 & 420 \\
\hline $\mathbf{5}$ & 3367 & 1598 & 1445 & 155 & 1510 & 655 & 502 & 410 \\
\hline
\end{tabular}

Table 5:Electronic absorption spectra $\left(\mathrm{cm}^{-1}\right)$ of copper(II) complexes $\mathbf{1}-\mathbf{5}$

\begin{tabular}{|c|c|c|c|}
\hline \multirow[b]{2}{*}{ Complex } & \multicolumn{3}{|c|}{$\lambda\left(\mathrm{cm}^{-1}\right)$} \\
\hline & ${ }^{2} B_{1 \mathrm{~g}} \rightarrow{ }^{2} B_{2 \mathrm{~g}}$ & ${ }^{2} B_{1 \mathrm{~g}} \rightarrow{ }^{2} A_{1 \mathrm{~g}}$ & ${ }^{2} B_{1 \mathrm{~g}} \rightarrow{ }^{2} E_{\mathrm{g}}$ \\
\hline 1.[ $\left.\mathrm{CuLL}^{\prime}\right] \mathrm{Br} . \mathrm{H}_{2} \mathrm{O}$ & 14436 & 16684 & 18232 \\
\hline 3. $\left[\mathrm{CuLL}^{\prime}\right] \mathrm{ClO}_{4} \cdot \mathrm{H}_{2} \mathrm{O}$ & 14557 & 16174 & 18799 \\
\hline 4. $\left[\left(\mathrm{CuLL}^{\prime}\right)_{2} \mathrm{SO}_{4}\right] \mathrm{H}_{2} \mathrm{O}$ & 14587 & 16873 & 18689 \\
\hline 5. $\left[\mathrm{CuLL}^{\prime}\right] \mathrm{NO}_{3} \cdot \mathrm{H}_{2} \mathrm{O}$ & 14962 & 16993 & 18368 \\
\hline & $\mathrm{dz}^{2} \rightarrow \mathrm{dx}^{2}-\mathrm{y}^{2}$ & $d_{x y} \rightarrow d x^{2}-y^{2}$ & $\mathrm{~d}_{\mathrm{xz}}, \mathrm{d}_{\mathrm{yz}} \rightarrow \mathrm{dx}^{2}-\mathrm{y}^{2}$ \\
\hline 2. $\left[\mathrm{CuLL}^{\prime} \mathrm{H}_{2} \mathrm{O}\right] \mathrm{Cl} . \mathrm{H}_{2} \mathrm{O}$ & 14155 & 16293 & 18196 \\
\hline
\end{tabular}


Table 6: ESR spectral parameters and magnetic moment values of copper(II) complexes 1-5

\begin{tabular}{|c|c|c|c|c|c|}
\hline Complex & $g_{\|}$ & $g_{\perp}$ & $g_{\mathrm{av}}$ & $G$ & $\mu_{\text {eff }}(\mathrm{BM})$ \\
\hline $\mathbf{1}$ & 2.243 & 2.045 & 2.111 & 5.400 & 1.93 \\
\hline $\mathbf{2}$ & 2.233 & 2.035 & 2.101 & 6.657 & 1.89 \\
\hline $\mathbf{3}$ & 2.257 & 2.056 & 2.123 & 4.589 & 1.87 \\
\hline $\mathbf{4}$ & 2.277 & 2.046 & 2.123 & 5.893 & 1.91 \\
\hline $\mathbf{5}$ & 2.268 & 2.053 & 2.124 & 5.056 & 2.12 \\
\hline
\end{tabular}

Kinetic studies on ligand substitution of cupper (II) complexes [Cu(II)(L-Val)(AMP)]X $(1, \mathrm{X}=\mathrm{Br}$; $2, \mathrm{X}=\mathrm{Cl}$; $5, \mathrm{X}=\mathrm{NO}_{3}$ )

To elucidate the biomimetic activity of copper(II) complexes, a detailedkinetic study on substitution was carried out. Thiourea was selected as a nucleophile because of its high nucleophilicity that prevents back reaction. [26].

Reactions of complexes 1, 2 and 5 with thiourea can be followed kinetically in the range of ca. 300-400 nm. Solutions were used by dissolving known amounts of complexes in methanol and the substitution reactions were studied as a function of TU concentration in methanol. Figure 1 shows UV/Vis spectral changes and Figures 2 show examples of the representative kinetic traces recorded at $350 \mathrm{~nm}$ using stopped-flow instrument.

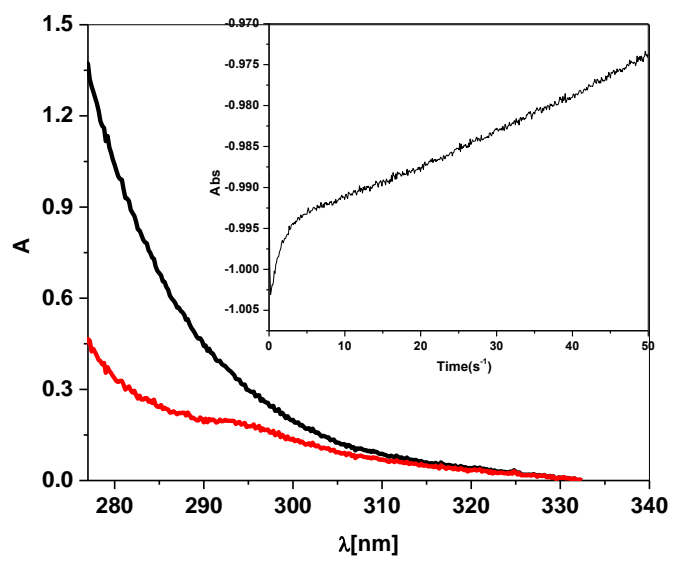

Figure 1. UV/Vis spectral changes measured during the reaction of $5\left(0.5 \times 10^{-4} \mathrm{M}\right)$ with thiourea $(250 \mathrm{mM})$ in methanol at $296 \mathrm{~K}$ : a) spectrum before the reaction; b) spectrum obtained 60 seconds after mixing of the reactants.
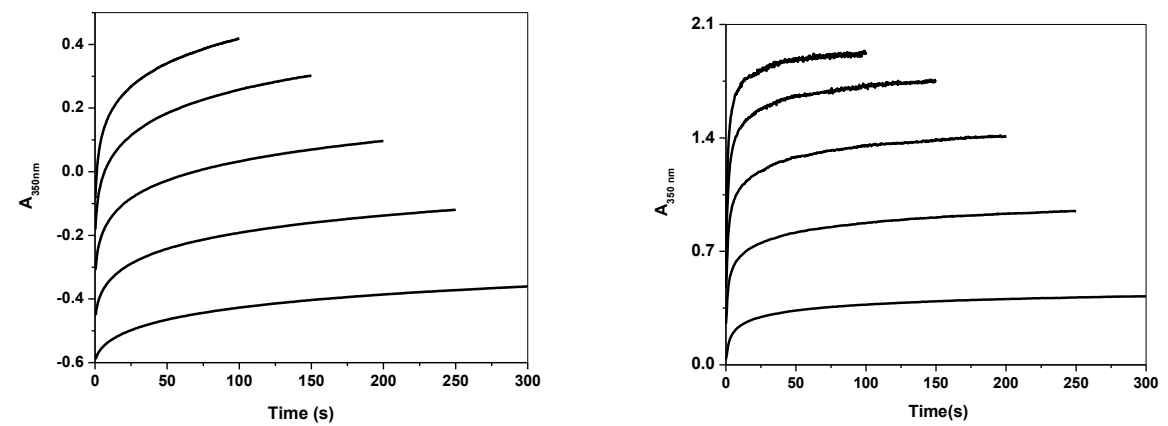

Figure 2. Absorbance-time traces at $350 \mathrm{~nm}$ for the reaction of $\mathbf{1}$ (left) and $\mathbf{2}$ (right) $\left(6 \times 10^{-4} \mathrm{M}\right)$ with thiourea in different concentrations in methanol at $296 \mathrm{~K}$ measured using stopped-flow instrument.

Rate constants for the reaction of complexes $\mathbf{1}, \mathbf{2}$ and $\mathbf{5}$ were measured by using total TU concentrations in range of $0.001-0.25 \mathrm{M}$ such that at least in $10 \square$ fold excess over the $\mathrm{Cu}$ (II) complexes. It was possible to fit the kinetic traces at the studied wavelength to a two-exponential function by using the following equation:

$$
A=a_{1} e^{-k_{\text {obsd } 1} t}+a_{2} e^{-k_{\text {obsd }} 2^{t}}+A_{0}
$$


The overall reactions with all complexes are biphasic; an initial fast reaction (rate constant $k_{\text {obsdl }}$ ) is followed by a slower one (rate constant $k_{o b s d 2}$ ). $k_{o b s d l}$ and $k_{o b s d 2}$ increase linearly with TU concentration (Figure 3 ), which leads to the second-order rate constants. The results demonstrate that the second substitution process is slowed down by ten orders of magnitude.

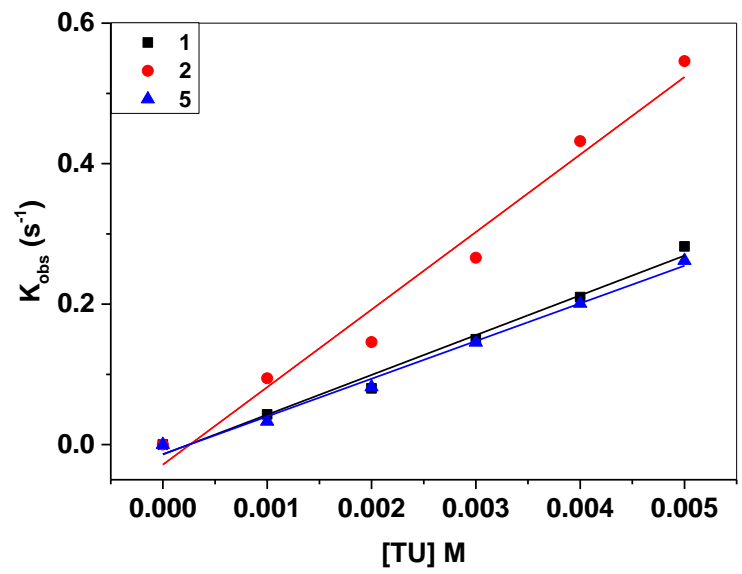

Figure 3. Plots of the first reaction step of $k_{\text {obsd }}$ vsthiourea concentration for complexes $\mathbf{1}(\mathbf{\square}), \mathbf{2}(\mathbf{\square})$ and $\mathbf{5}$ ( $\left.\mathbf{\Delta}\right)$ in methanol at $296 \mathrm{~K}$. Experimental conditions: [comp] $=6 \times 10^{-4} \mathrm{M}$.

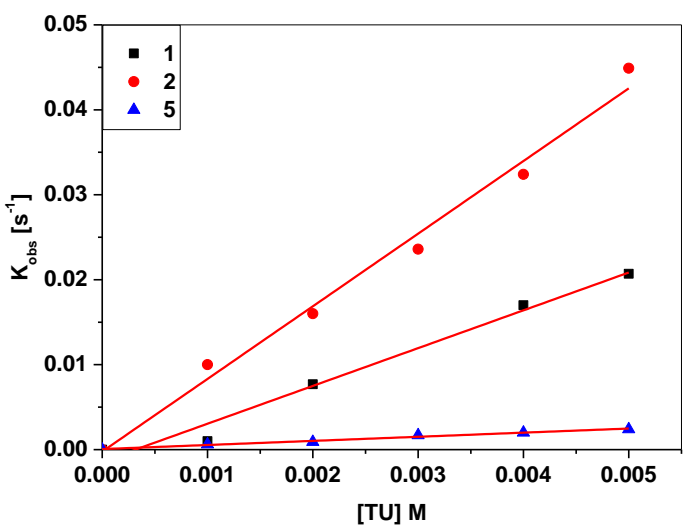

Figure 4. Plots of the second reaction step of $k_{o b s d}$ vsthiourea concentration for complexes $\mathbf{1}(\boldsymbol{\square}), \boldsymbol{2}(\bullet), 5(\boldsymbol{\Delta})$ in methanol at $296 \mathrm{~K}$. Experimental conditions: [complex] $=6 \times 10^{-4} \mathrm{M}$.

The observed kinetic behavior can be discussed for two subsequent substitution reactions (see equation 2, 3 and 4 ). The first and fast one is the displacement of solvent molecule (methanol) by one TU characterized by the secondorder rate constant $\mathrm{k}_{1}$. An evidence for the solvation process and coordination of methanol is the UV-spectra of the complexes in different solvent which indicate that the spectra is solvent dependent as shown in Figure 5. 

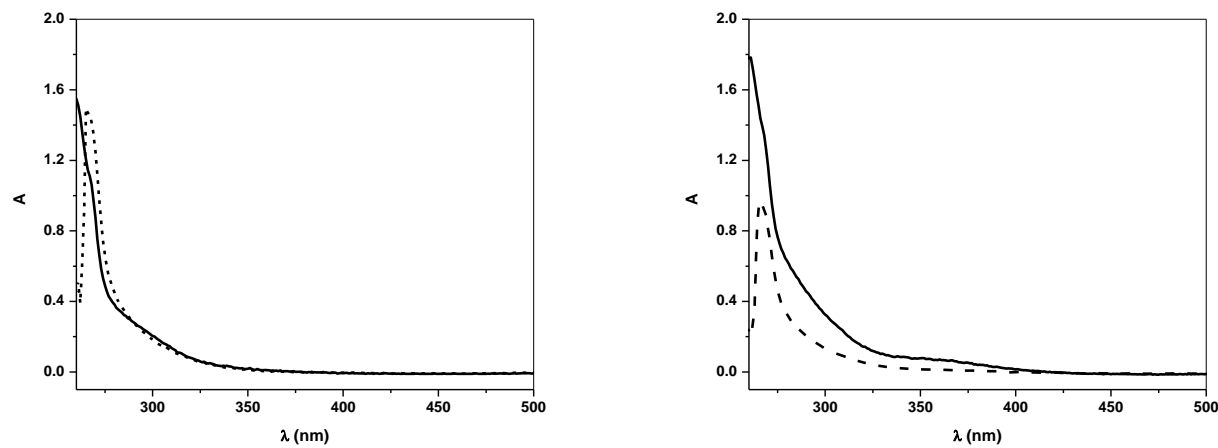

Figure 5. UV-vis spectra of complexes 1 (left)and2 (right) in methanol and DMF solvents at $296 \mathrm{~K}$. Experimental conditions: $[$ complx $]=6 \times 10^{-4} \mathrm{M}$.

The second substitution reaction can be discussed for the substitution of one arm of the ligand. The reaction scheme presented below shows that $k_{o b s l}$ and $k_{o b s 2}$ should depend linearly on the TU concentration in the absence of a back reaction as shown in Figures 4 and $k_{o b s l}=\mathrm{k}_{1}[\mathrm{Nu}]$ and $k_{o b s 2}=\mathrm{k}_{2}[\mathrm{Nu}]$. The rate constants in Table 1 show that the second substitution reactions are much slower than the first one (about ten times slower). An explanation for this could be the steric hindrance on the $\mathrm{Cu}$ (II) center found by the displacement of methanol by thiourea as well as to the lability of the methanol compared to the strong coordination affinity of the nitrogen arm of the ligand.A comparison of $\mathrm{k}_{1}$ and $\mathrm{k}_{2}$ (the first and second substitution reaction rates) of complexes $\mathbf{1}, \mathbf{2}$ and $\mathbf{5}$, shows that the counter ions have a role in the substitution process and are in the order of decreasing $\mathrm{Cl}>\mathrm{Br}>\mathrm{NO}_{3}{ }^{-}$. An explanation for this is that the mechanism is probably dissociative and as a result, the ions are affecting the rate or probably the size of the counter ion is playing an effect.

$$
[\mathrm{Cu}(\mathrm{L}-\mathrm{Val})(\mathrm{L})]^{+} \stackrel{\mathrm{MeOH}}{\longrightarrow} \quad[\mathrm{Cu}(\mathrm{L}-\mathrm{Val})(\mathrm{L})(\mathrm{MeOH})]^{+}
$$

$$
[\mathrm{Cu}(\mathrm{L}-\mathrm{Val})(\mathrm{L})(\mathrm{MeOH})]^{+} \underset{\mathrm{k}_{1}}{\stackrel{\mathrm{TU}}{\longrightarrow}}[\mathrm{Cu}(\mathrm{L}-\mathrm{Val})(\mathrm{L})(\mathrm{TU})]^{+}+\mathrm{MeOH}
$$

$$
[\mathrm{Cu}(\mathrm{L}-\mathrm{Val})(\mathrm{L})(\mathrm{TU})]^{+} \stackrel{\mathrm{TU}}{\underset{\mathbf{k}_{2}}{\longrightarrow}}\left[\mathrm{Cu}(\mathrm{L}-\mathrm{Val})(\mathrm{L})(\mathrm{TU})_{2}\right]^{+}
$$

Table 7. Summary of the second order rate constants for the substitution reactions using thiourea in $\left[\mathrm{Cu}^{\mathrm{II}}(\mathrm{AMP})\left(L_{-}\right.\right.$ $\mathrm{Val})] \mathrm{X}\left(\mathbf{1}, \mathrm{X}=\mathrm{Br} ; \mathbf{2}, \mathrm{X}=\mathrm{Cl} ; \mathbf{5}, \mathrm{X}=\mathrm{NO}_{3}\right)$ in methanol.

\begin{tabular}{|c|l|l|}
\hline Complex & Fast step, $K_{2}$ & Slow step, $K_{2}$ \\
\hline $\mathbf{1}$ & $56.6 \pm 3.3$ & $4.5 \pm 0.4$ \\
\hline $\mathbf{2}$ & $110.3 \pm 8.7$ & $8.6 \pm 0.5$ \\
\hline $\mathbf{5}$ & $50.0 \pm 3.3$ & $0.5 \pm 0.1$ \\
\hline
\end{tabular}


Oxidase biomimetic catalytic activity of $[\mathrm{Cu}(\mathrm{II})(\mathrm{L}-\mathrm{Val})(\mathrm{AMP})] \mathrm{X}\left(1, \mathrm{X}=\mathrm{Br} ; 2, \mathrm{X}=\mathrm{Cl} ; \mathbf{5}, \mathrm{X}=\mathrm{NO}_{3}\right)$ :In most of the enzyme like activity of synthetic model complexes, 3,5-di-tert-butylcatechol (3,5-DTBCH$\left.)_{2}\right)$ and oaminophenole $(\mathrm{OAPH})$ have been used as substrates. The product 3,5-di-tert-butyl-o-quinone (3,5-DTBQ) and 2amino-3H-phenoxazin-3-one (APX), respectively are stable and exihibt a strong absorption at $\lambda_{\max }=400$ and 420 $\mathrm{nm}$, respectively.[27] The reaction rates can be measured using electronic spectroscopy by following the appearance of the absorption maximum of the product. The reactivity studies were measured in methanol as a solvent because of the good solubility of the complexes, the substrate and its product in methanol. Firstly, the ability of complexes $\mathbf{1}-\mathbf{3}$ to oxidize both substrates is measured. By mixing 0.1 mMsolutions of complexes in methanol and $100 \mathrm{mM}$ of 3,5$\mathrm{DTBCH}_{2}$ or OAPH in the presence of air. The reaction was followed by UV/VIS spectroscopy. The first results showed that all complexes are reactive with both 3,5-DTBCH $\mathrm{H}_{2}$ and o-AP and examples for the catalytic reactions with a solution of complex $\mathbf{1}$ are shown in Figures 6.
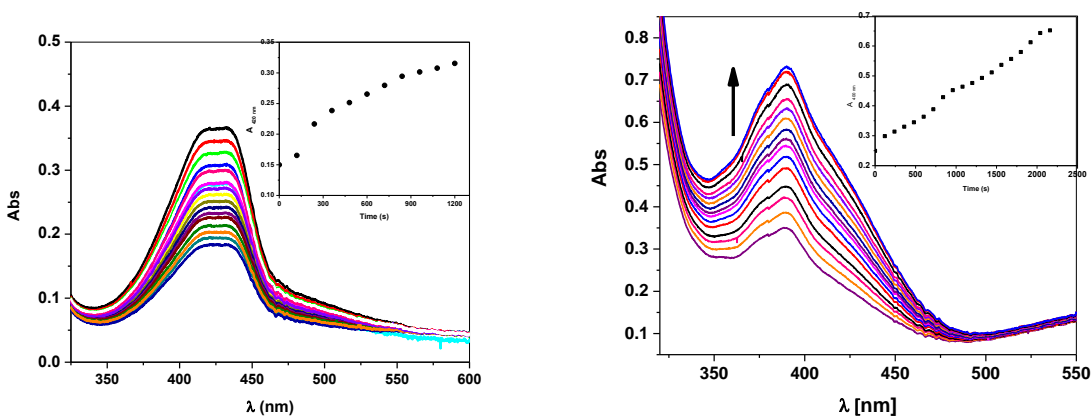

Figure 6. UV/Vis spectral changes measured for the reaction of $\mathbf{1}\left(6 \times 10^{-4} \mathrm{M}\right)$ with 3,5-DTBCH 2 (right) and OAPH (left) in $\mathrm{MeOH}$ at $296 \mathrm{~K}$. Insets are kinetic traces at 400 and $420 \mathrm{~nm}$ (in second) for 3,5-DTBC and OAP, respectively.

Figure 6 showed that the addition of substrate to the complexes has influence on the UV/Vis spectrum with respect to position and intensity. Therefore, binding of substrate to the copper(II) center should be considered as first step. We used stopped-flow techniques to study the first reaction and the nature of the coordination of substrate to the metal center in more detail. The complexes spectra change upon addition of substrate during the first seconds as shown in Figure 7. The kinetic traces of this reaction could be followed at 400 and $420 \mathrm{~nm}$ for 3,5-DTBCH${ }_{2}$ and $\mathrm{OAPH}$, respectively. The kinetics of the subsequent slow reaction was followed by the initial rate method at the specified wave length.
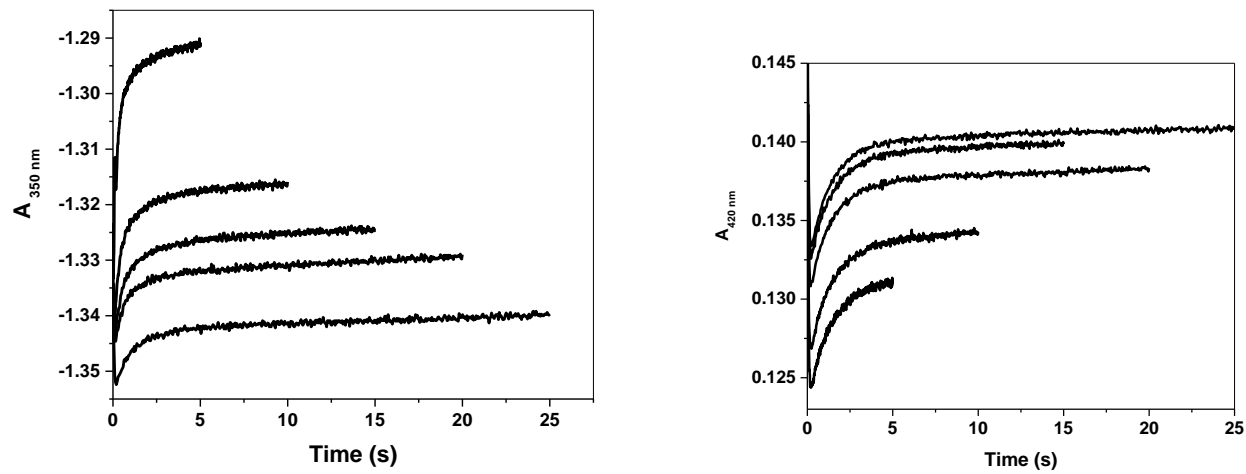

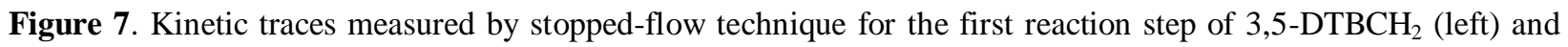
$\mathrm{OAPH}$ (right) with 1 in $\mathrm{MeOH}$ at $296 \mathrm{~K}$.

The results in Figure 7 show that the kinetic traces plot in both cases proceeds in two steps. The second step is absent when the experiment is repeated under inert atmosphere (i.e. in the absence of oxygen), indicating that the formed band is due to oxidized form. To get the dependence of the reaction rates on the substrate concentration, solution of complexes was treated with different concentrations of both substrates in methanol as solvents. A first-order 
dependence on the substrate concentration was observed in both cases for the first step, as presented in Figures 8 and 9.

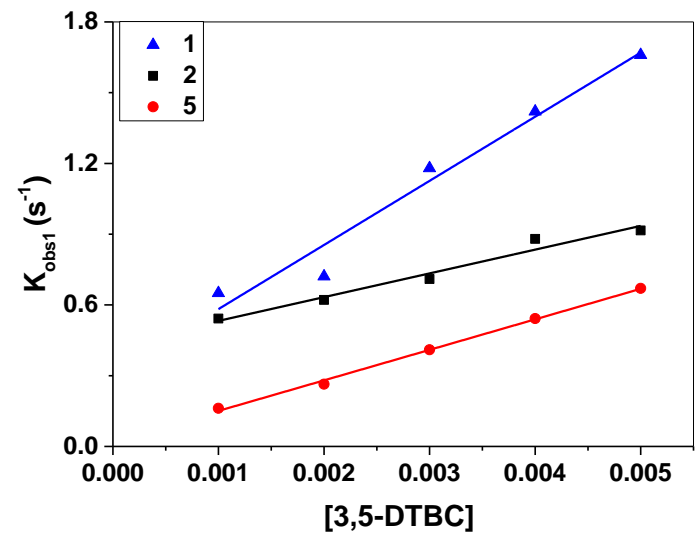

Figure 8. Plot of $k_{\text {obsl }}$ vs. 3,5-DTBCH $\mathrm{D}_{2}$ concentration for the first step in the reaction with $0.5 \times 10^{-4} \mathrm{M}$ of complexes $\mathbf{1}(\boldsymbol{\Delta}), \mathbf{2}(\mathbf{\bullet})$ and $\mathbf{5}(\bullet)$ in $\mathrm{MeOH}$ at $296 \mathrm{~K}$.

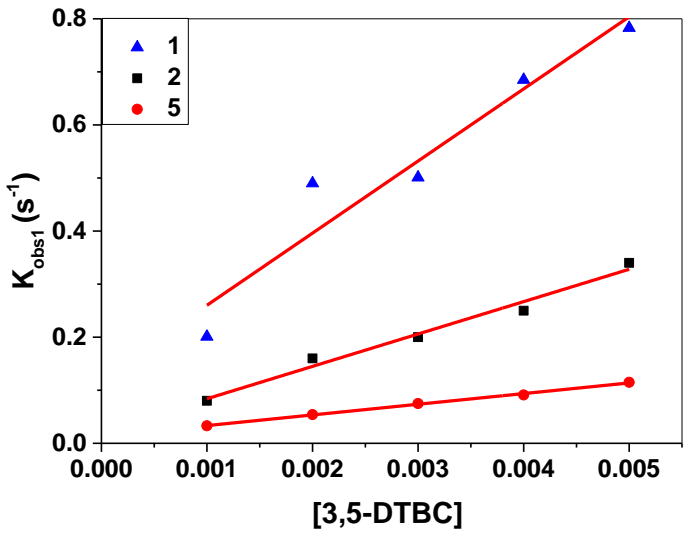

Figure 9. Plot of $k_{o b s l} v s$. OAPH concentration for the first step in the reaction with $0.5 \times 10^{-4} \mathrm{M}$ of complexes $\mathbf{1}(\boldsymbol{\Delta})$, 2(घ) and5(•) in $\mathrm{MeOH}$ at $296 \mathrm{~K}$. 
Table 8 . Comparison of catalytic parameters of selected model systemsCu(II)(L-Val)(AMP)]X $(\mathbf{1}, \mathrm{X}=\mathrm{Br} ; \mathbf{2}, \mathrm{X}=$ $\mathrm{Cl} ; \mathbf{5}, \mathrm{X}=\mathrm{NO}_{3}$ ).

\begin{tabular}{|c|c|c|c|c|c|c|c|}
\hline \multicolumn{2}{|r|}{ Comp } & $k_{l}$ & $k_{-1}$ & $K_{1}=$ & $k_{\text {cat }}$ & $K_{M} \times 10^{-4}$ & $K_{c a t} / K_{M}$ \\
\hline \multirow[t]{2}{*}{1} & $\begin{array}{c}3,5- \\
\mathrm{DTBCH}_{2} \\
\end{array}$ & $271 \pm 29$ & $0.31 \pm 0.09$ & 874 & $2.13 \pm 0.40$ & $24.4 \pm 9.9$ & 672 \\
\hline & $\mathrm{OAPH}$ & $135 \pm 21$ & $0.13 \pm 0.07$ & 1038 & $12.8 \pm 0.64$ & $23 \pm 3$ & 5565 \\
\hline \multirow[t]{2}{*}{2} & $\begin{array}{c}3,5- \\
\mathrm{DTBCH}_{2}\end{array}$ & $100 \pm 10$ & $0.43 \pm 0.03$ & 232 & $3.36 \pm 0.20$ & $55.1 \pm 4.2$ & 609 \\
\hline & OAPH & $61 \pm 5$ & $0.10 \pm 0.02$ & 610 & $10.3 \pm 0.7$ & $18 \pm 3.4$ & 5722 \\
\hline \multirow[t]{2}{*}{5} & $\begin{array}{c}3,5- \\
\text { DTBCH }_{2} \\
\end{array}$ & $129 \pm 4$ & $0.04 \pm 0.01$ & 3225 & $1.49 \pm 0.4$ & $3.1 \pm 0.4$ & 1892 \\
\hline & OAPH & $20 \pm 1$ & $0.01 \pm 0.00$ & 2000 & $7.4 \pm 0.8$ & $21 \pm 0.5$ & 3523 \\
\hline \multicolumn{2}{|c|}{$\begin{array}{c}\text { Catechol } \\
\text { oxidase from } \\
\text { I. batatas [28] }\end{array}$} & & & & 2.29 & 25.0 & 916 \\
\hline
\end{tabular}

The formation of a rapid pre-equilibrium involving adduct formation between the $\mathrm{Cu}$ (II) complexes and substrate can be proposed (see equation 5). Similar results have been observed by our group and reported recently.[29] The results measured for both substrates show that, except for complex 3 , the coordination affinity of $3,5-\mathrm{DTBCH}_{2}\left(K_{1}=\right.$ $k_{1} / k_{\square l} \mathrm{M}^{-1}$ ) is lower than of OAPH (see table 2). An explanation for this may be the higher basicity of OAP in methanol compared to 3,5- $\mathrm{DTBCH}_{2}$ and also the high steric hinderence of 3,5-DTBCH 2 compared to OAPH.

$\mathrm{Cu}^{\text {II }}$ comp + Substrate Fubstrate adductCu ${ }^{\text {II }}$ comp + Product (5)

The results show that for the second reaction step between substrates and complexes, a first-order dependence on the substrate concentration was observed at low concentrations of substrate. Whereas at higher substrate concentrations, saturation kinetics was observed (see Figure 5). The irreversible conversion into the oxidized product is considered to be the rate-determining step, i.e. $k_{2}<<k_{-1}$ and $K_{l}=k_{l} / k_{-1}$. The rate law for the reaction sequence in (6) is given by (7):

$$
V=\frac{d[\text { Product }]}{d t}=k_{2}\left[\text { Cu } u^{I I} \operatorname{comp}-\text { adduct }\right]=\frac{k_{2} K_{1}\left[\text { Cu }{ }^{I I} \text { comp }\right][\text { Substrate }]}{1+K_{1}[\text { Substrate }]}
$$

where $V$ is the rate of product formation, which can be rewritten as

$$
\frac{V}{\left[\text { Cu } u^{I I} \text { complex }\right]}=\frac{k_{2} K_{1}[\text { substrate }]}{1+K_{1}[\text { substrate }]}
$$

The maximum rate constant, $k_{2}$, is reached when the catalyst is completely saturated with substrate or at high [substrate]. The results showed that all complexes $\mathbf{1}$ - $\mathbf{3}$ have higher activity for the oxidation of OAPH compared to that of 3,5-DTBCH 2 and is in the range of the enzyme itself from I. batatas [28].

The reaction rate is linearly dependent on the concentration for all complexes, indication for a first-order dependence on catalyst concentration (see an example shown in Figure 12). 


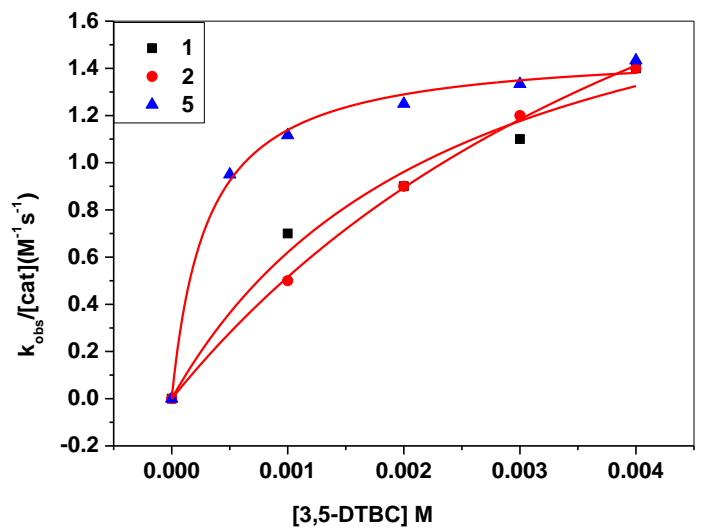

Figure 10.Dependence of the initial rate of the oxidation reaction of 3,5-DTBCH $\mathrm{H}_{2}$ on the concentration of the substrate 3,5-DTBCH $\mathrm{H}_{2}$ catalyzed by complexes $\mathbf{1}(\mathbf{\bullet}), \mathbf{2}(\bullet)$ and $\mathbf{5}(\mathbf{\Delta})$ in methanol. The concentration of complexes was $0.5 \times 10^{-4} \mathrm{M}$ and the reaction was followed at $400 \mathrm{~nm}$.

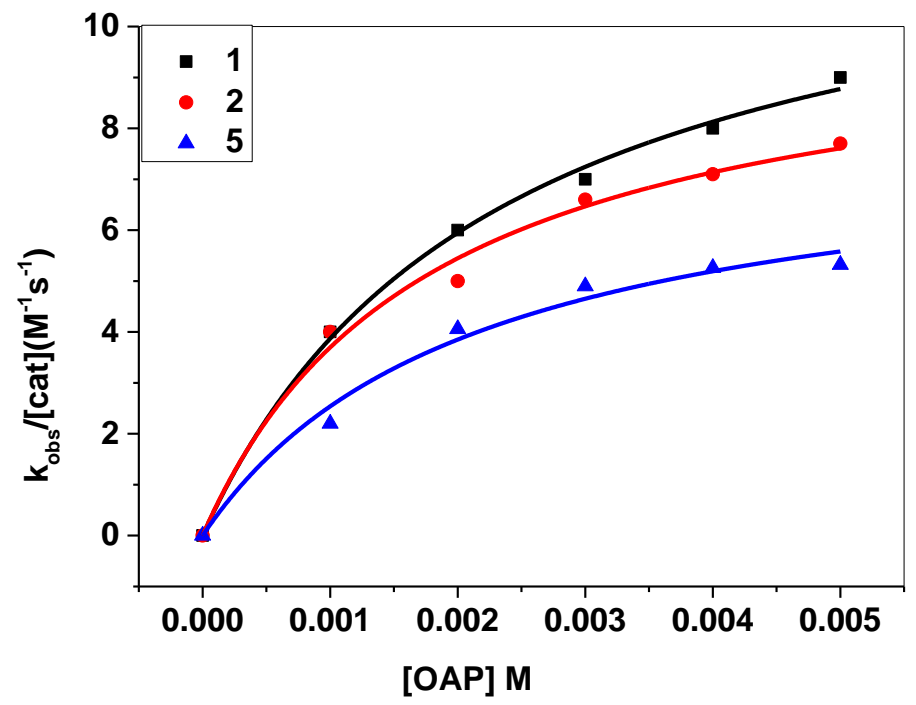

Figure 11.Dependence of the initial rate of the oxidation reaction of OAPH on the concentration of the substrate OAP catalyzed by $\mathbf{1}(\bullet), \mathbf{2}(\bullet)$ and $\mathbf{5}(\boldsymbol{\Delta})$ in methanol. [comp] $=0.5 \times 10^{-4} \mathrm{M}$ and $\lambda=400 \mathrm{~nm}$.

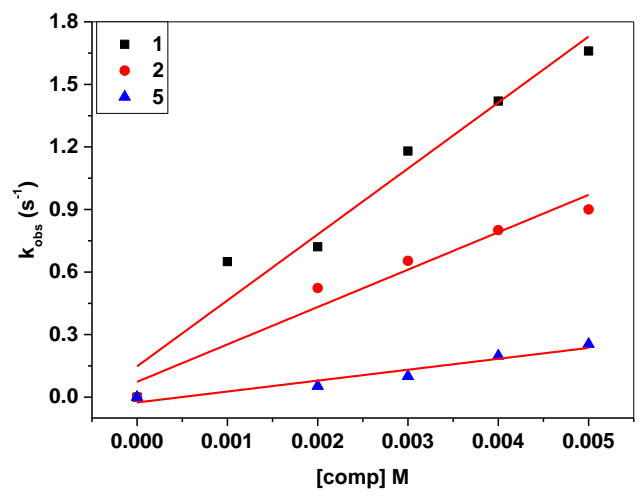

Figure 12. Plots of the first reaction step of $k_{o b s d} \mathrm{Vs}$ complex concentration $\mathbf{1}(\boldsymbol{\bullet}), \mathbf{2}(\bullet), \mathbf{5}(\mathbf{\Delta})$ in methanol at $296 \mathrm{~K}$. Experimental conditions: $\left[3,5-\mathrm{DTBCH}_{2}\right]=10^{-3} \mathrm{M}$. 


\section{Conclusion:-}

In a quest of mimicking the catechol oxidase and Phenoxazinone synthase, a series of mononuclear cupper (II) complexes containing 2-aminomethylpyridine (AMP) and $L$-valine ( $L$-Val) have been synthesized and completely characterized. The biomimetic activity has been studied in details and structural-activity relationship has been correlated. In general, the results show that the coordination affinity towards 3,5-DTBCH$\left(K_{l}=k_{l} / k_{-l} \mathrm{M}^{-1}\right)$ is lower than of OAPH and as a result all complexes have higher activity for the oxidation of OAP compared to that of 3,5$\mathrm{DTBCH}_{2}$.

\section{References:-}

1. M. N. Hughes. The Inorganic Chemistry of Biological Processes, $2^{\text {nd }}$ edn., John Wiley \& Sons: New York. (1981).

2. a) Wang, A.R. Parrish, L. Wang. Expanding the genetic code for biological studies.Chem. Biol., 2009, 16 (3), 323;b) P. Newsholme, L. Stenson, M. Sulvucci, R. Sumayao, M. Krause.Amino Acid Metabolism.Comprehensive Biotechnology (Second Edition). 1: 3-14, 2011.

3. M. Hakimi, T. S. Aliabadi, World Applied Programming, 2012, 2(10), 431.

4. a)M. Markovic, N. Judas, J. Sabolovic,Inorg. Chem. 2012, 50, 3632; b) T. Murakami, S. Kita.Inorg.Chim.Acta, 1998, 274, 247; c) A.K.Patra, A.R.Chakravarty, Proc.IndianNatn.Sci.Acad.2007, 73, 157; d) X. H. Zhou, X.Y.Lee, S. Chen, J.Coord.Chem.2005, 58, 993; e) B. Lou, X. Huang, X. Lin. Z.Anorg.Allg.Chem.2007,633, 372; f) X. Le, S. Liao, X. Liu, X. Feng. J.Coord.Chem.2006,59, 985; g) M.Markovic, N.Judas, J.Sabolovic, Inorg.Chem.2011, 50, 3632.

5. M. Shukla, N. Srivastava, S. Saha, T.R. Rao,S. Sunkari, Polyhedron, 2011, 30, 754.

6. E. I. Solomon, U. M. Sundaram, T. E. Machonkin, Chem. Rev. 1996, 96, 2563.

7. J. C. Freeman, P. G. Nayar, T. P. Belgely, J. J. Villafranca, Biochemistry, 1993, 32, 4826

8. W.J. Geary, Coord. Chem. Rev. 1971, 7,81

9. A.W. Coats, J.P. Redfern, Nature, 1964,68,201.

10. J. Dehand, J. Jordanov, F. Keck, A. Mosset, J.J. Bonnet, J. Galy, Inorg. Chem.1979, 18, 1543.

11. L.M. Marcotrigiano, L. Menabue, G.C. Fellacani, M. Saladini, M. Sola. Inorg. Chem., 1985, 24, 3621.

12. X. Le, S. Liaoy, X. Liuy, X. Feng, J. Coord. Chem.2006, 69(9), 985.

13. K. Nakamoto. Infrared and Raman Spectra of Inorganic and Coordination Compounds, $3{ }^{\text {rd }}$ Edn., John Wiley and Sons Inc., New York (1978).

14. L.M. Marcotrigiano, L. Menabue, G.C. Fellacani, M. Saladini, M. Sola. Inorg. Chem.,1985, 24, 3621.

15. W.Radecka-Paryzek, V. Patroniak-Krzyminiewska, H. Litkowska, Polyhedron, 1998, 17, 1477.

16. a) A. B. P. Lever, Inorganic Electronic Spectroscopy, Elsevier, Amsterdam, 1970; b) K. Singh, M. S. Barwa, P. Tyagi, Eur. J. Med. Chem. 2007, 42, 394; c) Y. Li, C. Yan, Z. Wu, C. Zhu, J. Mag. Mag. Mater. 2005, 292, 418.

17. a) T. A. Khan, S. Naseem, S. N. Khan, A. U. Khan, M. Shakir, Spectrochim. Acta 2009, A73, 622; b) N. Raman, C. Thangaraja, S. Johnsoraja, Central Eur. J. Chem.2005, 3, 537.

18. A.B.P. Lever, Inorganic Electronic Spectroscopy, $2^{\text {nd }}$ ed., Elsevier, New York. 1984

19. a) O.O.E. Onawumi, O. O. P. Faboya, O. A. Odunola, T. K. Prasad, M. V. Pajasekharan, Polyhedron,2008, 27, 113; b) R. N. Patel, N. Singh, D. K. Patel, V.L.N.Gundla, Indian J Chem., 2007, 422; c) N. M. El-Metwaly, I. M. Gabr, A. A. El-Asmy, Transition Met. Chem., 2006, 31, 71.

20. A.S. Fernandes, J. gaspar, M.F. Cabral, C. Caneiras, R. Guedes, M. Castro, J. Costa, N.G. Oliveira, J. Inorg. Biochem. 2007, 101, 849.

21. D. Kivelson, R. Neiman, J. Chem. Phys. 1961, 35, 149.

22. a) D.X. West, I. Thientaravanich, A.E. Liberta, Trans. Met. Chem. 1995, 20, 303; b) A.M. Ramadan, I. M. ElMehasseb, Trans. Met. Chem.1998, 23, 183.

23. I. Fidone, K.W.H. Stevens, Proc. Phys. Soc. London, 1959, 73, 116.

24. B.J. Hathaway, D.E. Billing, Coord. Chem. Rev. 1970, 5, 143.

25. B.J. Hathaway, R.J. Dudley, P. Nicholls, J. Chem. Soc. A1968, 1845.

26. a) A. Hofmann, D. Jaganyi, O.Q. Munro, G. Liehr, R. van Eldik. Inorg.Chem. 2003, 42, 1688; b) S.Y. Shaban, F.W. Heinemann, R. van Eldik.Eur. J. Inorg. Chem., 2009, 3111.

27. J. Reim, B. Krebs J. Chem. Soc., Dalton Trans., 1997, 3793; b) O. Y. ishida, K. Ida, S. Kida, Bull. Chem. Soc. Jpn., 1980, 53, 2847.

28. S. J. Smith, C. J. Noble, R. C. Palmer, G. R. Hanson,G. Schenk, L. R. Gahan, M. J. Riley, J. BiolInorg Chem., 2008, 13, 499.

29. S.Y. Shaban, A. M. Ramadan, R. van Eldik, J. Coord. Chem., 2012, 65(14), 2415. 